\title{
High Antimony Source and Geochemical Behaviors in Mine Drainage Water in China's Largest Antimony Mine
}

\author{
Cheng Li ${ }^{1,2}$, Chunming Hao ${ }^{3,4,2 *}$, Wei Zhang ${ }^{3}$, Herong Gui ${ }^{4}$ \\ 'Xi'an University of Science and Technology, Shaanxi, P.R. China \\ ${ }^{2}$ Key Laboratory of Mine Geological Hazards Mechanism and Control, Shaanxi, P.R. China \\ ${ }^{3}$ North China Institute of Science and Technology, Hebei, P.R. China \\ ${ }^{4}$ National Engineering Research Center of Coal Mine Water Hazard Control, Suzhou University, Anhui, P.R. China
}

Received: 7 October 2019

Accepted: 1 December 2019

\begin{abstract}
The $\mathrm{Sb}$ source and the formation process of high $\mathrm{Sb}$-contaminated mine water have not been well investigated. In this study, 11 mine water samples, 2 rainwater samples, 4 surface water samples, $4 \mathrm{D}_{3} \mathrm{x}^{4}$ (MA) water samples, and $4 \mathrm{D}_{3} \mathrm{~s}^{4}(\mathrm{SA})$ water samples were collected from the largest antinomy mine in China. The $\delta^{34} \mathrm{~S}, \delta^{18} \mathrm{O}$, and $\delta^{2} \mathrm{H}$ data and the water-rock interactions were analyzed to reveal the source of $\mathrm{Sb}$ and geochemical behaviors of the mine drainage water. The Sb concentrations in mine water samples are 238-2420 times higher than the maximum acceptable $\mathrm{Sb}$ concentration $(0.005 \mathrm{mg} / \mathrm{L})$, according to China's national drinking water quality standards. The chemical composition of the mine water is $\mathrm{Ca}-\mathrm{Na}-\mathrm{SO}_{4}$, and the SA water is the main source of the mine water. It is also revealed that the $\mathrm{Sb}$ pollutant in the mine water is derived from the oxidation of stibnite. Moreover, the soluble oxygen in the mine water and the ion-exchange interaction between the mine water and surrounding rocks also contribute to the formation of high Sb-contaminated mine water. This study provides valuable information for $\mathrm{Sb}$ pollutant source control and water body protection in a mine area.
\end{abstract}

Keywords: antimony pollution, water-rock interaction, stable isotopes analysis, mine drainage water, geochemical source

\section{Introduction}

Antimony $(\mathrm{Sb})$ is a versatile metal element and has found applications in flame retardants, batteries, solar cells, and semiconductor industries. The increasingly widespread usage of $\mathrm{Sb}$ has caused environmental

*e-mail: haocm@ncist.edu.cn pollution. Recently, Sb has been detected in soil, water, river sediment, plants, and groundwater - especially in areas around $\mathrm{Sb}$ mines [1]. The Xikuangshan Mine in Hunan, China, known as the world's antimony capital [2], currently accounts for $90 \%$ of the world's total antimony ore production [3]. Numerous studies have been carried out in this area to evaluate the multimedia environmental pollution caused by $\mathrm{Sb}$ [4-6]. The Qingfeng and Xuanshan rivers, two main tributaries of the Zijiang River, have already been heavily polluted 
by the discharge of mine water [7]. The $\mathrm{Sb}$ content in the river water varies from $0.02-8.12 \mathrm{mg} / \mathrm{L}$, which is 36-1624 times higher than the maximum acceptable $\mathrm{Sb}$ concentration $(0.005 \mathrm{mg} / \mathrm{L})$ according to China's national drinking water quality standards $[2,3,8]$. It has been reported that the $\mathrm{Sb}$ concentration in the pollution source, the $\mathrm{Sb}$ mine drainage, has reached 6064-7502 $\mu \mathrm{g} / \mathrm{L}$ [9]. In contrast, the Sb concentration in a non-polluted water body is below $1.0 \mu \mathrm{g} / \mathrm{L}[3,10$, 11]. With an increasing amount of attention paid to the surface water pollution, the source and the formation process of high Sb-containing mine water are often neglected. Hence, further investigation is of great importance to fully understand $\mathrm{Sb}$ sources and their geochemical behaviors.

In nature, $\mathrm{Sb}$ is mainly found as the sulfide mineral stibnite $\left(\mathrm{Sb}_{2} \mathrm{~S}_{3}\right)$. With the presence of oxygen, $\mathrm{Sb}$ can be mobilized into surrounding water bodies [11-13]. During this process, the chemical characteristic and isotope composition of the water bodies are changed. Hence, the formation process of Sb-contaminated water can be revealed by analyzing the chemical characteristics and isotope compositions of the surrounding water bodies. Sulfate is a useful marker for studying waters derived from both natural and anthropogenic sources. The elevated sulfate concentration in natural water is an indication of water deterioration [14]. Additionally, the sources, transportation, and transformation of the sulfate contaminates can be determined by analyzing the isotope compositions of sulfur and oxygen in sulfate anion [15-19]. Moreover, water-rock interactions have a strong influence on the chemical characteristics of water bodies [20-22]. For example, the dissolution of carbonate minerals leads to the rise of $\mathrm{Ca}^{2+}$ and $\mathrm{Mg}^{2+}$ contents, and the ion-exchange process often increases $\mathrm{Na}^{+}$and $\mathrm{K}^{+}$contents $[22,23]$.

The mining process of antimony deposits requires a high volume of drainage. When the amount of water inflow is greater than the amount of circulating water, the excess mine water must be discharged into the surrounding surface water body, resulting in $\mathrm{Sb}$ pollution. Hence, in this study, we investigated the source of $\mathrm{Sb}$ and geochemical behaviors of the mine drainage water using sulfate and oxygen isotope analysis and water-rock interaction method. The conclusions and observations obtained from this study provide valuable information for $\mathrm{Sb}$ pollutant source control and water body protection in the mine area.

\section{Material and Methods}

\section{Study Area}

This study was carried out in a $26 \mathrm{~km}^{2}$ area in Xikuangshan Mine, which is in the northern part of Xiangzhong Basin. This mine is a monoclinal formation, which follows the axis of an anticline striking $\mathrm{NE} 30^{\circ}$ and plunging both at north and south sends. The west wing has an $\mathrm{F}_{75}$ fracture and a boundary of a lamprophyre vein. The climate in this area is a monsoon-influenced humid subtropical climate with average precipitation and average evaporation of $1381.60 \mathrm{~mm}$ and $903.30 \mathrm{~mm}$, respectively. Moreover, the average temperature of the Xikuangshan Mine is $16.70^{\circ} \mathrm{C}$. Many gullies have been developed in the area, and the two main rivers are the Xuanshan and Qingfeng - seasonal rivers belonging to the Zijiang River system.

The antimony deposit is a layered breccia-type metal deposit in a structural fracture belt. The main mineral is stibnite. The aquifers, starting from top to bottom, are $\mathrm{D}_{3} \mathrm{x}^{4}$ (denoted as MA water) and $\mathrm{D}_{3} \mathrm{~s}^{2}$ (denoted as SA water) [2, 24], which are dominated by fissure-karst water. They have poor water abundance and are mainly composed of mudstone, silicified limestone, and sandy limestone. Generally, the upper and lower aquifers have no hydraulic connection with each other.

The $\mathrm{Sb}$ mining history in Xikuangshan Mine dates to $1897[25,26]$. After over 120 years of mining, a large amount of waste residues and ore pillars are abandoned in the goaf. It is estimated that the amount of $\mathrm{Sb}_{2} \mathrm{~S}_{3}$ left in ore pillars is about 1.85 million tons. Due to the interaction between $\mathrm{Sb}$ minerals and oxygen gas, a significant amount of $\mathrm{Sb}$ element has been mobilized into the groundwater $[26,27]$.

\section{Sample Collection and Analysis}

A total of 25 water samples (including 11 mine water samples, 2 rainwater samples, 4 surface water samples, 4 MA water samples, and 4 SA water samples) were collected during the dry season between September and November in 2016 (Fig. 1). The surface water samples were collected from the Qingfeng River. Before collection, each sample bottle was washed with distilled water and followed with the water sample for 2-3 times. Each water sample was filtered by a $0.45 \mu \mathrm{m}$ glass fiber membrane after collection and then filled three $500 \mathrm{~mL}$ sample bottles and one $10 \mathrm{~L}$ bottle. These three $500 \mathrm{~mL}$ samples were for hydrogen and oxygen isotope analysis, cation and anion concentration analysis, and $\mathrm{Sb}$ analysis, respectively. The $10 \mathrm{~L}$ sample was reserved for sulfur isotope analysis. Then, the $\mathrm{pH}$ values of the samples for $\mathrm{Sb}$ analysis and sulfur isotope analysis were adjusted to below 2.0 by adding 1:1 nitric acid (concentrated nitric acid/distilled water $=1 / 1$ ). Lastly, a recovery indicator (an $\mathrm{Sb}$ solution) was added into each sample bottle followed with vigorous shaking.

The concentrations of major anions (chloride ions, bicarbonate ions, and sulfate ions) and major cations (calcium ions, magnesium ions, sodium ions, and potassium ions) in each water sample were determined by ion chromatography (Dionex Integration IC, Thermo Fisher, U.S.). The obtained data shows high analytical precision with low ionic balance error (generally within $5 \%$ ). The $\mathrm{Sb}$ concentrations of the water samples were analyzed using an Agilent $7700 \times$ inductively coupled 
mass spectrometer (ICP-MS) with indium as the internal standard [2]. Each analysis was performed in triplicate to ensure precision and accuracy. The obtained data, which has less than $10 \%$ in the standard deviation and more than $95 \%$ recovery rate of the recovery indicator, was discussed in the following statistical analysis. The $\mathrm{pH}$ values and TDS values were obtained in the field by using a portable acidity meter (HANNA H18424) and an EC meter (HANNA H1833), respectively.

The analysis of stable isotope ${ }^{2} \mathrm{H}$ and ${ }^{18} \mathrm{O}\left(\mathrm{H}_{2} \mathrm{O}\right)$ were performed by using a Micromass MultiPrep equipped with a dual inlet and an isotope ratio mass spectrometers (IRMS) (Institute of Hydrogeology and Geology, Chinese Academy of Geological Sciences). The analytical uncertainties of the data obtained from this device are $\pm 0.1 \%$ for $\delta^{18} \mathrm{O}\left(\mathrm{H}_{2} \mathrm{O}\right)$ and $\pm 1 \%$ o for $\delta^{2} \mathrm{H}\left(\mathrm{H}_{2} \mathrm{O}\right)$. The $\delta^{34} \mathrm{~S}\left(\mathrm{SO}_{4}{ }^{2-}\right)$ and $\delta^{18} \mathrm{O}\left(\mathrm{SO}_{4}{ }^{2-}\right)$ values analysis were extracted as $\mathrm{BaSO}_{4}$ with $\mathrm{pH}$ adjusted to less than 2 to prevent the formation of $\mathrm{BaCO}_{3}$. The

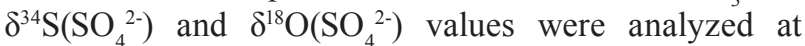
the China University of Geosciences (Wuhan) using a Micromass IsoPrime stable IRMS. The analytical precision is $0.2 \%$.

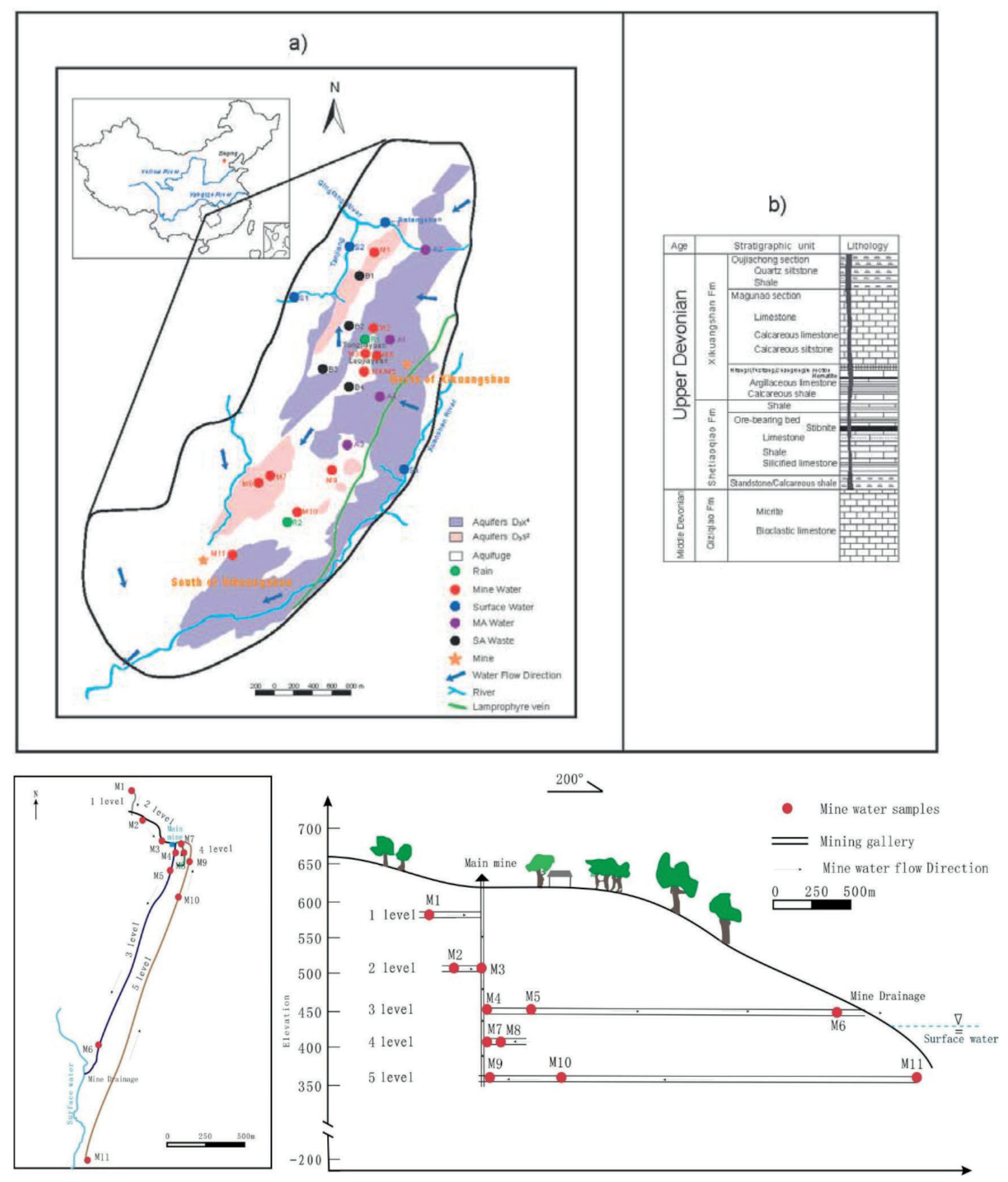

Fig. 1. Study area map and locations of sampling sites. 


\section{Results}

\section{Geochemical Characterization}

The major ion concentration, $\mathrm{Sb}$ content, TDS content, $\mathrm{pH}$, and isotope contents of each sample are listed in Table 1. The average Sb concentrations of mine water, rainwater, surface water, SA water, and MA water are $4.82 \mathrm{mg} / \mathrm{L}, 0.04 \mathrm{mg} / \mathrm{L}, 3.16 \mathrm{mg} / \mathrm{L}, 1.65 \mathrm{mg} / \mathrm{L}$, and $0.21 \mathrm{mg} / \mathrm{L}$, respectively - all of which exceed the maximum acceptable $\mathrm{Sb}$ concentration $(0.005 \mathrm{mg} / \mathrm{L})$ according to China's national drinking water quality standards. The mine water sample, M6, has the highest $\mathrm{Sb}$ concentration among the collected water samples, which is 2420 times the maximum acceptable $\mathrm{Sb}$ concentration for drinking water, and 24.20 times of the maximum acceptable $\mathrm{Sb}$ concentration of wastewater $(0.50 \mathrm{mg} / \mathrm{L})$ according to the local discharge regulations (Hunan Province, China). Moreover, the $\mathrm{Sb}$ concentrations in different water bodies show a decreasing trend: mine water $>$ surface water $>\mathrm{SA}$ water $>\mathrm{MA}$ water $>$ rainwater. The relatively low $\mathrm{Sb}$ content in MA water and rainwater and the high $\mathrm{Sb}$ content in mine water indicates that the $\mathrm{Sb}$ pollution is caused by mining activities [2].

A Piper diagram is a graphical approach to represent the chemical characteristics and water-rock interactions of water samples [28]. The Piper diagram of these water samples was plotted in Fig. 2. According to the Piper classification, the hydrochemical types of mine water, rainwater, groundwater, $\mathrm{SA}$ water, and $\mathrm{MA}$ water are $\mathrm{Ca}-\mathrm{Na}-\mathrm{SO}_{4}$ type, $\mathrm{Ca}-\mathrm{HCO}_{3}$ type, $\mathrm{Ca}-\mathrm{HCO}_{3}-\mathrm{SO}_{4}$ type,

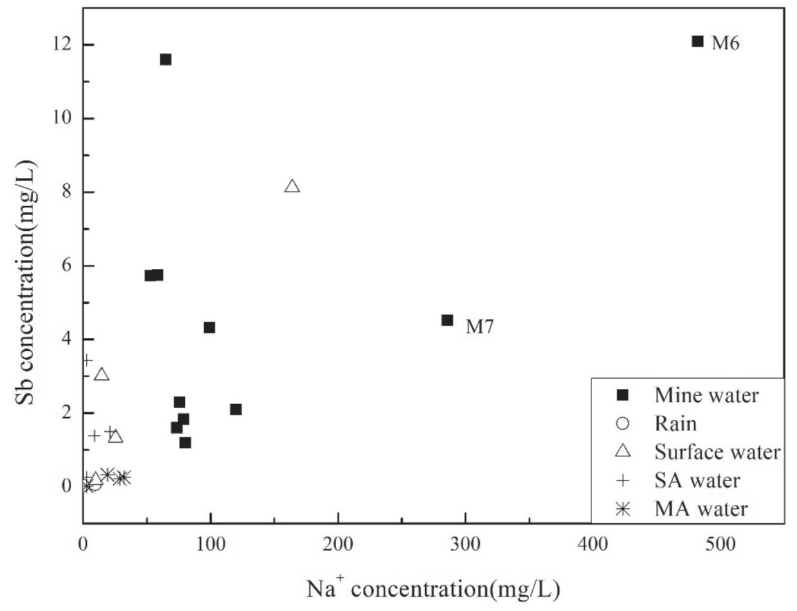

Fig. 3. Relationship between $\mathrm{Na}^{+}$and $\mathrm{Sb}$ for samples collected in the study.

$\mathrm{Ca}-\mathrm{SO}_{4}-\mathrm{HCO}_{3}$ type, and $\mathrm{Ca}-\mathrm{HCO}_{3}-\mathrm{SO}_{4}$, respectively. Compared with other water bodies, the mine water has higher contents of $\mathrm{Sb}$ (Fig. 2), $\mathrm{Na}^{+}$(Fig. 3), TDS (Fig. 4), and $\mathrm{SO}_{4}^{2-}$ (Fig. 5), suggesting that the $\mathrm{Sb}$ element is more likely to concentrate in high TDS, high $\mathrm{Na}^{+}$, and high $\mathrm{SO}_{4}^{2-}$ water bodies [2]. Moreover, the $\mathrm{Sb}$ contents in the mine water samples show a weak correlation with the contents of $\mathrm{Na}^{+}$, TDS, or $\mathrm{SO}_{4}^{2-}$ (Figs 2-5) - implying that the $\mathrm{Sb}$ in mine water originates from multiple sources.

The water-rock interaction process of $\mathrm{Sb}_{2} \mathrm{~S}_{3}$ can be written as follows [15, 29]:

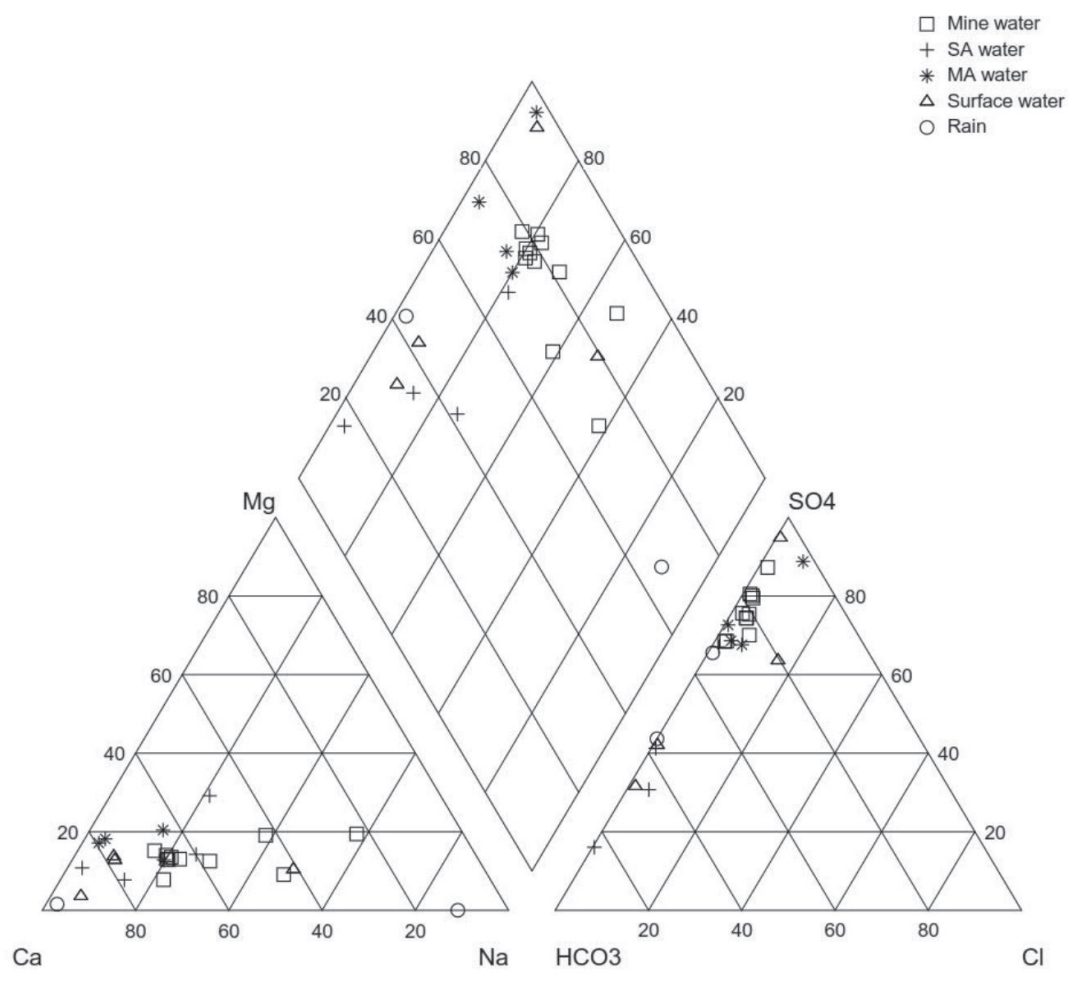

Fig. 2. Piper diagram of ionic composition of different groundwaters in the study area. 


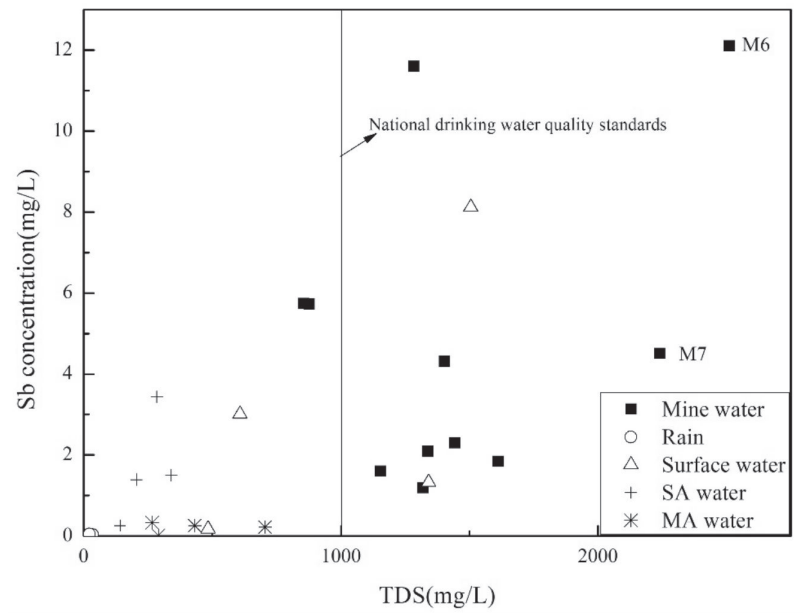

Fig. 4. Relationship between TDS and Sb for samples collected in the study; note: the TDS value of each sample was measured in the field using a portable EC meter (HANNA H1833).

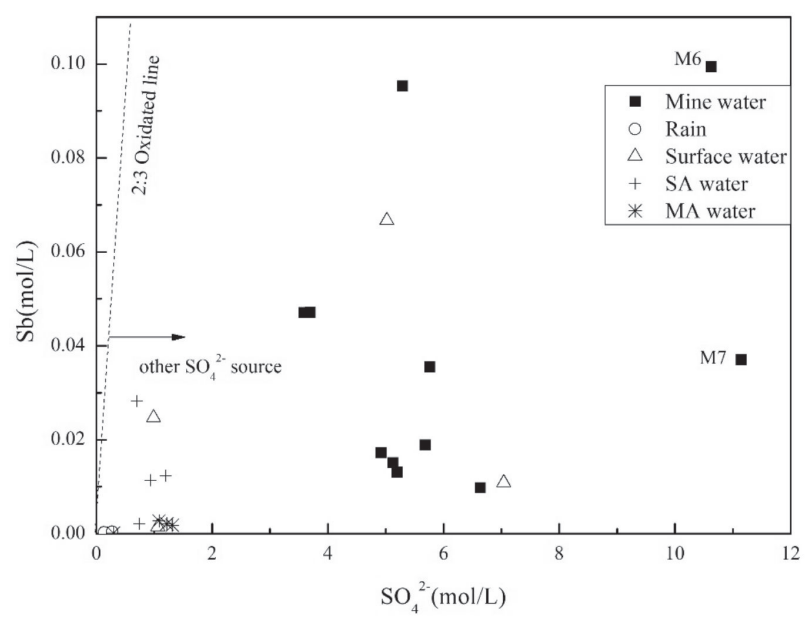

Fig. 5. Relationship between $\mathrm{SO}_{4}{ }^{2-}$ and $\mathrm{Sb}$ for samples collected in the study.

$$
\begin{gathered}
\mathrm{Sb}_{2} \mathrm{~S}_{3}+3 \mathrm{H}_{2} \mathrm{O}+6 \mathrm{O}_{2}=2 \mathrm{Sb}_{2} \mathrm{O}_{3}+3 \mathrm{SO}_{4}{ }^{2-}+6 \mathrm{H}^{+} \\
\mathrm{Sb}_{2} \mathrm{~S}_{3}+8 \mathrm{CaCO}_{3}+7 \mathrm{O}_{2}+10 \mathrm{H}_{2} \mathrm{O}=2 \mathrm{Sb}(\mathrm{OH})_{6}^{-} \\
+8 \mathrm{Ca}^{2+}+3 \mathrm{SO}_{4}{ }^{2-}+8 \mathrm{HCO}_{3}^{-}
\end{gathered}
$$

As shown in Equation (1), a large amount of $\mathrm{H}^{+}$ is produced. The $\mathrm{pH}$ values of mine water samples, however, range from 7.78 to 8.86 , indicating that the $\mathrm{H}^{+}$produced from the water-rock interaction has been neutralized by carbonate mineral. If $\mathrm{Sb}_{2} \mathrm{~S}_{3}$ is the only source of $\mathrm{SO}_{4}^{2-}$ in water bodies in this area, based on equation (2), the mole ratio between $\mathrm{Sb}$ element and $\mathrm{SO}_{4}^{2-}$ should be close to 2:3. However, as shown in Fig. 5, all collected water samples show a much higher concentration of $\mathrm{SO}_{4}^{2-}$, indicating that the $\mathrm{SO}_{4}^{2-}$ in these water samples has multiple sources. Besides, as the solubility of $\mathrm{CaSO}_{4}$ is much lower than that of $\mathrm{CaHCO}_{3}$, with the rise of $\mathrm{Ca}^{2+}$ concentration, the content of $\mathrm{SO}_{4}^{2-}$ will decrease. As shown in Fig. 6, the actual

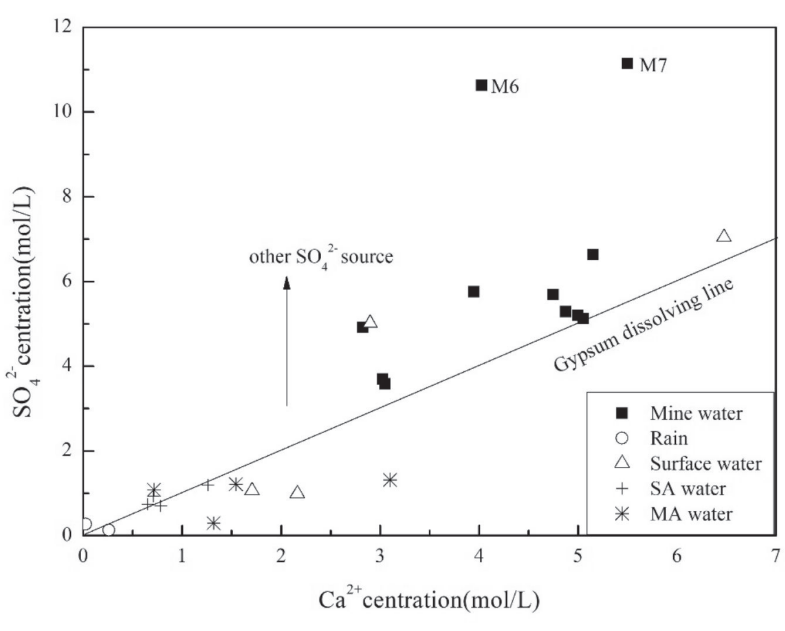

Fig. 6. Relationship between $\mathrm{SO}_{4}^{2-}$ and $\mathrm{Ca}^{2+}$ for samples collected in the study.

$\mathrm{SO}_{4}^{2-}$ contents of mine water samples are all above the gypsum dissolving line. This evidence further verifies the presence of other $\mathrm{SO}_{4}^{2-}$ sources.

\section{Isotope Geochemistry}

\section{Analysis of ${ }^{2} \mathrm{H}$ and ${ }^{18} \mathrm{O}$ Isotopes}

Hydrogen and oxygen isotopic fractionation processes have been widely used in water source analysis and water cycle study. The isotope composition of water changes along with physicochemical processes, such as evaporation and water-rock interactions [30]. The $\delta^{18} \mathrm{O}\left(\mathrm{H}_{2} \mathrm{O}\right)$ values and $\delta^{2} \mathrm{H}$ values of these water samples were plotted in Fig. 7. Apart from M6 and M7 (labeled in Fig. 7), the $\delta^{18} \mathrm{O}\left(\mathrm{H}_{2} \mathrm{O}\right)$ values and $\delta^{2} \mathrm{H}$ values of mine water samples appear in-between the $\operatorname{GMWL}\left(\delta^{2} \mathrm{H}=8 \delta^{18} \mathrm{O}\left(\mathrm{H}^{2} \mathrm{O}\right)+10\right)[31,32]$ and $\operatorname{LMWL}\left(\delta^{2} \mathrm{H}=8.38 \delta^{18} \mathrm{O}\left(\mathrm{H}^{2} \mathrm{O}\right)+17.3\right)[33,34]$, suggesting that these water samples are influenced by the evaporation effect. Besides, the high $\delta^{18} \mathrm{O}\left(\mathrm{H}_{2} \mathrm{O}\right)$ values in M6 and M7 (labeled in Fig. 7) may be caused by the water-rock interaction [35].

The $\delta^{18} \mathrm{O}\left(\mathrm{H}_{2} \mathrm{O}\right)$ and $\delta^{2} \mathrm{H}$ values of $\mathrm{SA}$ water samples are very close to that of mine water samples (Fig. 7), indicating that SA water is the main water source of mine water. Moreover, one MA water sample, B4, and two surface water samples, S2 and S4 (highlighted in an outline of an ellipsoid in Fig. 7) show similar $\delta^{18} \mathrm{O}\left(\mathrm{H}_{2} \mathrm{O}\right)$ and $\delta^{2} \mathrm{H}$ values as mine water samples, suggesting that B4, S2, and S4 sampling sites have hydraulic connections with the mine water. As shown in Fig. 1, the discharged mine water may accumulate at S2 and S4 surface water sampling sites, which are located at the lowest position of all water bodies in this area. The evidence of the hydraulic connections between the MA water, B4, and mine water suggests that the mining activities have already destroyed the aquifuge between the SA aquifer and MA aquifer. 


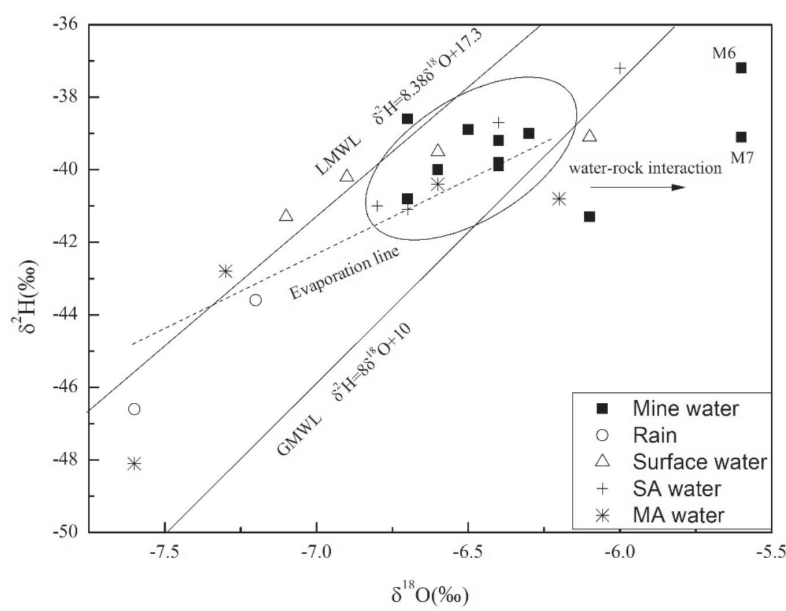

Fig. 7. Relationship between $\delta^{18} \mathrm{O}\left(\mathrm{H}_{2} \mathrm{O}\right)$ and $\delta^{2} \mathrm{H}$ for samples collected in the study.

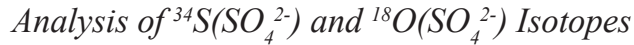

$\delta^{34} \mathrm{~S}\left(\mathrm{SO}_{4}^{2-}\right)$ and $\delta^{18} \mathrm{O}\left(\mathrm{SO}_{4}{ }^{2-}\right)$ analysis plays an important role in studying the transformation and migration of the sulfur element in sulfide ore deposits $[16,18,36]$. In mine water samples, $\delta^{34} \mathrm{~S}_{\left(\mathrm{SO}_{4}{ }^{2-}\right) \text { ranges }}$ from $-0.10 \%$ to $+6.10 \%$ and $\delta^{18} \mathrm{O}\left(\mathrm{SO}_{4}{ }^{2-}\right)$ ranges from $+1.10 \%$ to $+8.30 \%$. Multiple sulfate minerals found in this mine, including pyrite $(-0.78 \%$ o to $+33.40 \%)$, lamprophyre $(-6.30 \%$ o to $+2.30 \%)$, stibnite $(-3.27 \%$ o to $+16.83 \%$ ), and gypsum $(-3.27 \%$ to $+16.83 \%$ ), contribute to the sulfate cations in the mine water samples [37, 38].

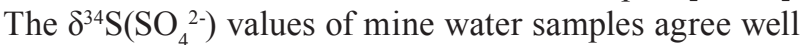

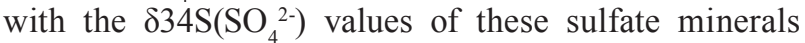
(Fig. 8).

\section{Discussion}

\section{Water-Rock Interaction}

The $\mathrm{Ca}^{2+} / \mathrm{Na}^{+}$and $\mathrm{Mg}^{+} / \mathrm{Na}^{+}$mole ratios in a water body is closely related to the dissolution process of evaporites, carbonates, and silicates during the waterrock interaction [23]. As shown in Fig. 9, the mole ratios of $\mathrm{Ca}^{2+} / \mathrm{Na}^{+}$and $\mathrm{Mg}^{+} / \mathrm{Na}^{+}$of all these water samples appear between carbonate and silicate dissolution, indicating that the chemical composition of water bodies in this area is influenced by carbonates and silicates. Compared with SA water, the $\mathrm{Ca}^{2+} / \mathrm{Na}^{+}$and $\mathrm{Mg}^{+} / \mathrm{Na}^{+}$ mole ratios of mine water samples, especially M6 and M7, are closer to the silicate dissolution, suggesting that the mine water contains a high level of silicate minerals (Table 1).

The relationship between cations and anions in a water body is a powerful indicator of the source and evolution process of its chemical composition. For instance, the influence of ion-exchange interaction on the chemical composition of a water body can be evaluated by the concentration of $\left(\mathrm{Ca}^{2+}+\mathrm{Mg}^{2+}-\mathrm{HCO}_{3}^{-}\right.$ $\left.-\mathrm{SO}_{4}{ }^{2-}\right)$ versus the concentration of $\left(\mathrm{Na}^{+}+\mathrm{K}^{+}-\mathrm{Cl}\right)$ in $\mathrm{meq} / \mathrm{L}$ [39-42]. With a strong ion-exchange interaction, the data points of water samples will lie along a line with a slope of -1 . The concentration of $\left(\mathrm{Ca}^{2+}+\mathrm{Mg}^{2+}-\right.$ $\left.\mathrm{HCO}_{3}{ }^{-}-\mathrm{SO}_{4}{ }^{2-}\right)$ versus the concentration of $\left(\mathrm{Na}^{+}+\mathrm{K}^{+}-\mathrm{Cl}{ }^{-}\right)$ in meq/L was plotted in Fig. 9 [43]. All the data points of the mine water samples are in the second quadrant of the plot, indicate an access amount of $\mathrm{Na}$ and $\mathrm{K}$ cations, which is evidence of ion-exchange reactions during the water-rock interaction of mine water. Additionally, the data points of these mine water samples (except M7 and M6) follow the fitting line with a slope of -1 , suggesting

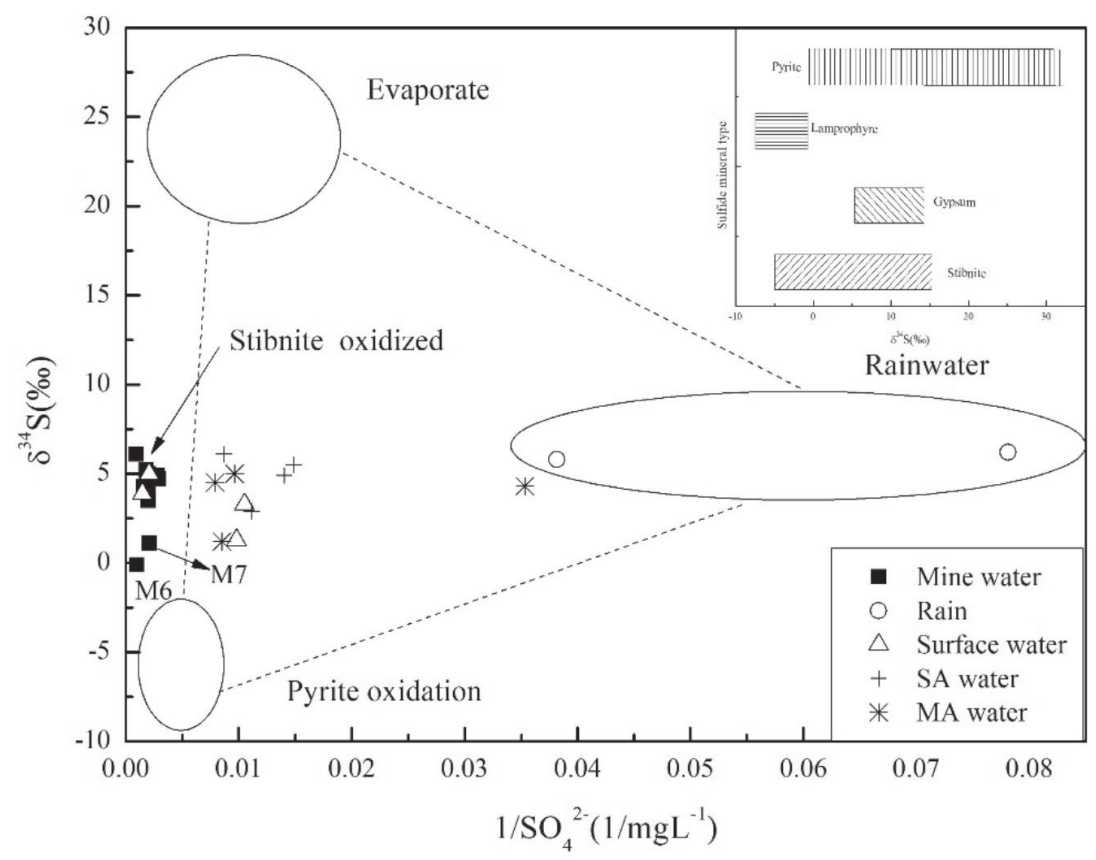

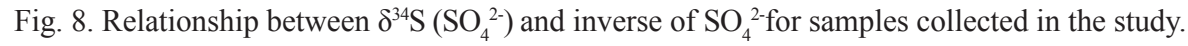




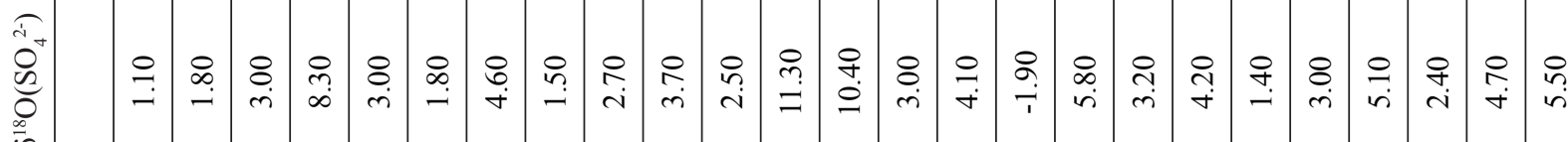

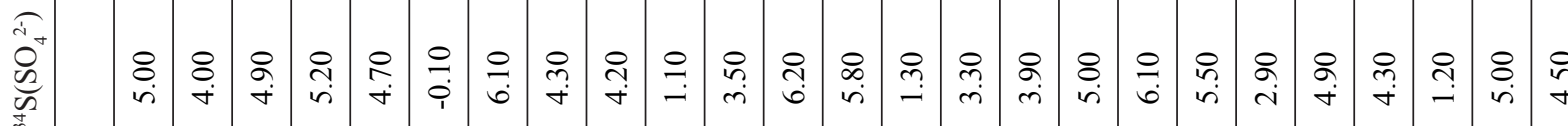
๑

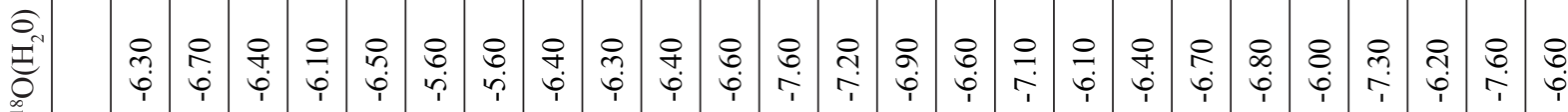

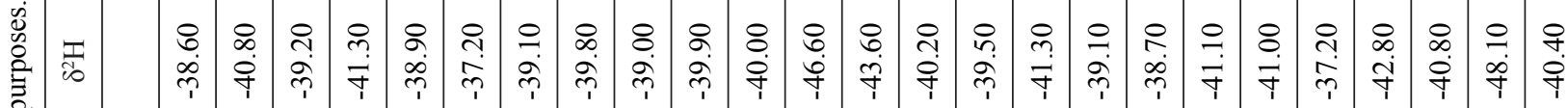

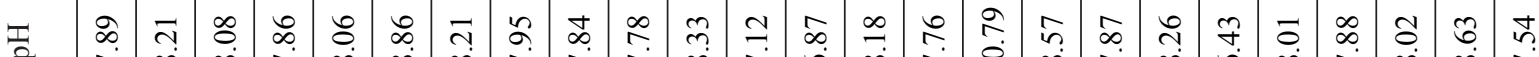

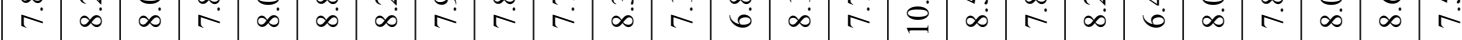

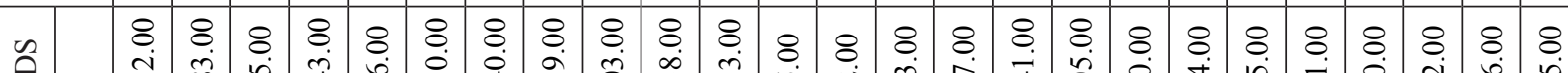

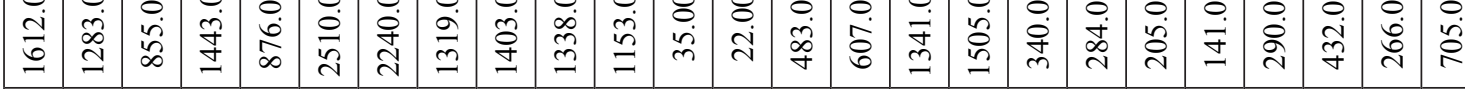

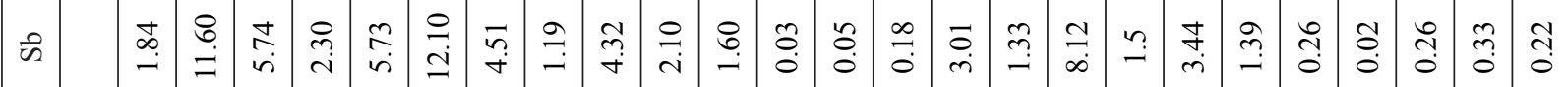

0.

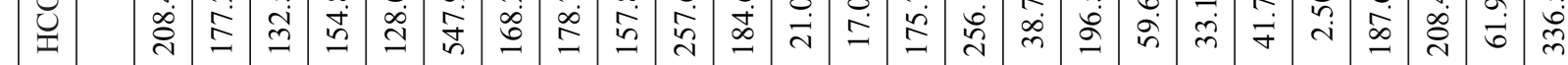

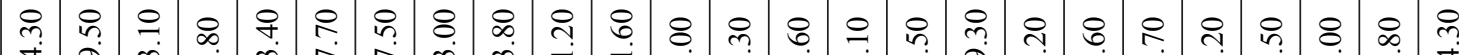
i

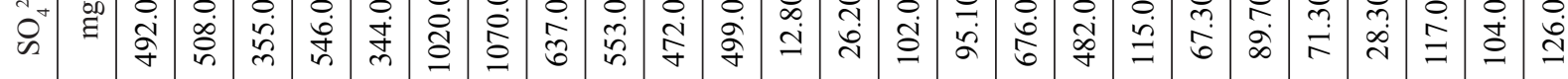

a $\sum^{\infty}$ ते

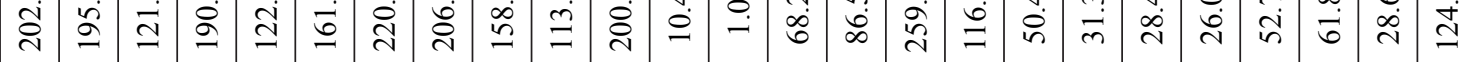
\&

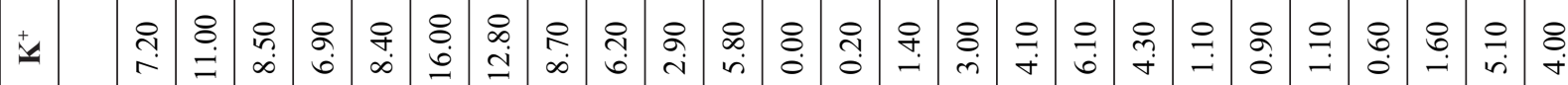

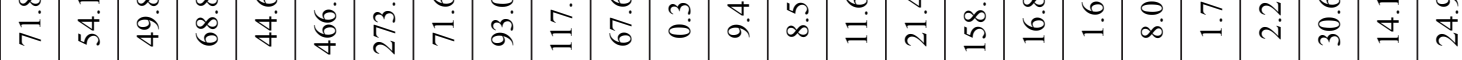

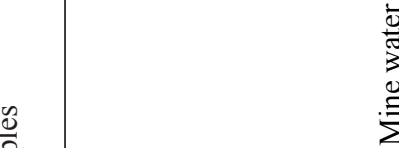

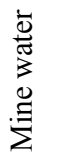

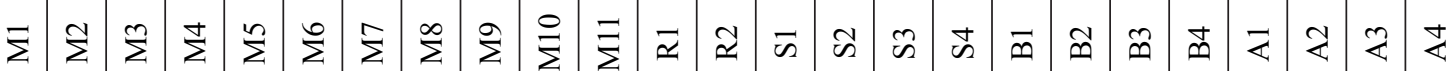




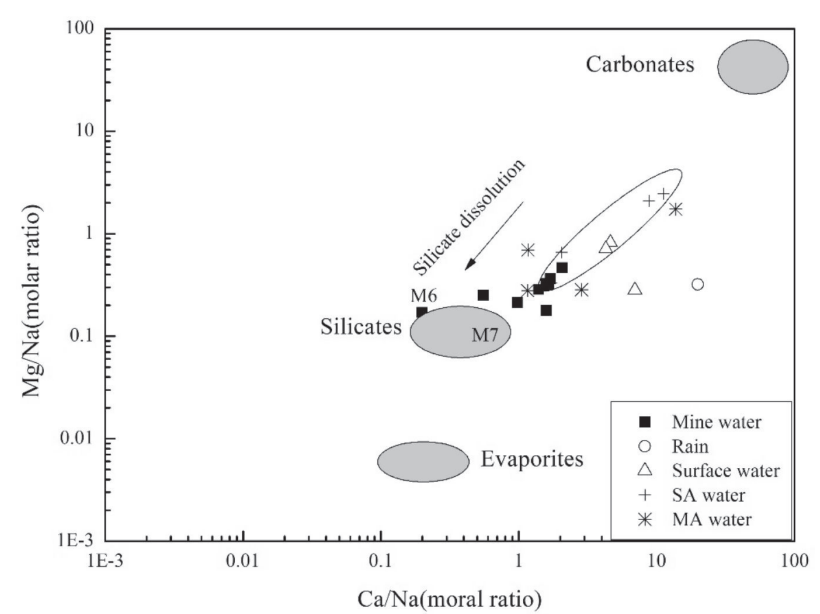

Fig. 9. Diagrams for determining the end member compositions by $\mathrm{Mg} / \mathrm{Na}$ vs. $\mathrm{Ca} / \mathrm{Na}$ molar ratios.

that the ion-exchange process plays a key role in the formation of mine water. Besides, M7 and M6 appear above the fitting line with higher concentrations of $\mathrm{Ca}$ cation and $\mathrm{Mg}$ cation compared with that of other mine water samples. As M6 and M7 are collected at the main drainage of the mine water (Fig. 10), the high flow rate promotes the dissolution of carbonate minerals. Moreover, compared with the SA water samples, the mine water samples have high $\left(\mathrm{Na}^{+}+\mathrm{K}^{+}-\mathrm{Cl}^{-}\right)$, which is additional evidence of cation ion-exchange interaction that occurred during the formation of the mine water.

\section{The Source of $\mathrm{SO}_{4}^{2-}$ in Mine Water}

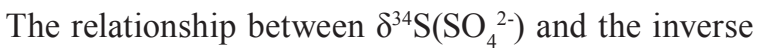
value of $\mathrm{SO}_{4}{ }^{2-}$ content is commonly used to analyze the source of sulfate in a water body [18, 19, 44].

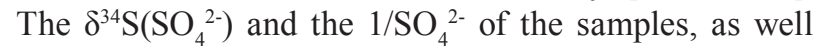
as the value ranges of $\left.\delta^{34} \mathrm{~S}_{(} \mathrm{SO}_{4}{ }^{2-}\right)$ and $1 / \mathrm{SO}_{4}{ }^{2-}$ of three

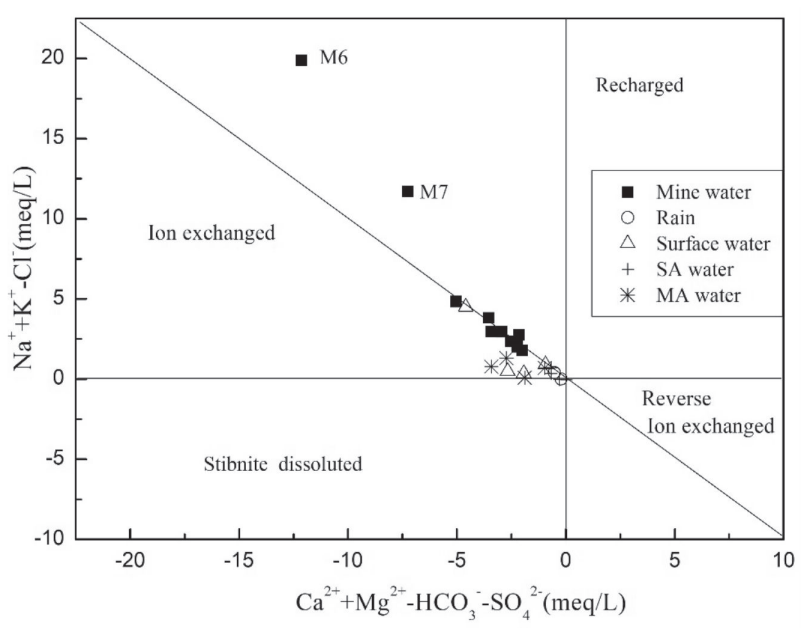

Fig. 10. Relationship between $\mathrm{Ca}^{2+}+\mathrm{Mg}^{2+}-\mathrm{HCO}_{3}^{-}-\mathrm{SO}_{4}{ }^{2-}$ and $\mathrm{Na}^{+}+\mathrm{K}^{+}-\mathrm{Cl}^{-}$for samples collected in the study. main sulfate sources (sulfide oxidation, evaporate, and rainwater) were plotted in Fig. 8. The sulfide oxidation appears in the bottom left side of the plot with a high

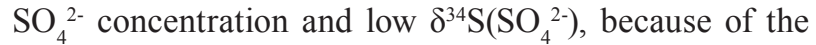
influence of a sulfate-reducing bacteria $[15,19,26]$. The evaporated sulfate source with high $\mathrm{SO}_{4}^{2-}$ and

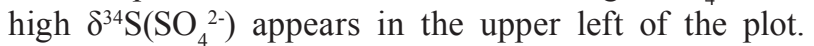
The rainwater generally has a low level of $\mathrm{SO}_{4}{ }^{2-}$ and a

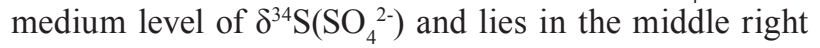
of the plot (Fig. 8).

Generally, the smaller the distance between a sulfate source and a water sample in the plot, the stronger the influence of the sulfate source on the sulfate in a water sample becomes, and vice versa. As shown in Fig. 7, the data points of the mine water samples lie close to the sulfide oxide source, suggesting that sulfide oxidation is the main source of the sulfate cations in mine water. Rainwater is not the source of the sulfate cations in mine water due to the large differences in sulfate concentrations. This statement can also be confirmed in the $\delta^{18} \mathrm{O}\left(\mathrm{H}_{2} \mathrm{O}\right)$ and the $\delta^{2} \mathrm{H}$ analysis in Fig. 7. Compared with the SA water, the mine water has a higher concentration of $\mathrm{SO}_{4}^{2-}$.

The relative proportions of oxygens derived from water can be calculated by the following equation [44-46]:

$$
\begin{gathered}
\delta^{18} \mathrm{O}\left(\mathrm{SO}_{4}^{2-}\right)=\mathrm{X}\left(\delta^{18} \mathrm{O}\left(\mathrm{H}_{2} \mathrm{O}\right)+\mathrm{EH}_{2} \mathrm{O}\right) \\
+(1-\mathrm{X})\left(\delta^{18} \mathrm{O}\left(\mathrm{O}_{2}\right)+\mathrm{EO}_{2}\right)
\end{gathered}
$$

...where $\mathrm{X}$ is a coefficient and $\mathrm{EH}_{2} \mathrm{O}$ and $\mathrm{EO}_{2}$ are the isotope enrichment factors for the incorporation of oxygen from water and atmospheric oxygen, respectively. Fig. 11 was plotted based on the data calculated from Equation (3).

As shown in Fig. 11, about $75 \%$ percent of sulfate oxygen atoms in the mine water (except the M4 sample) is derived from water. This result agrees with previous works, where Sun et al. and Seal et al. investigated

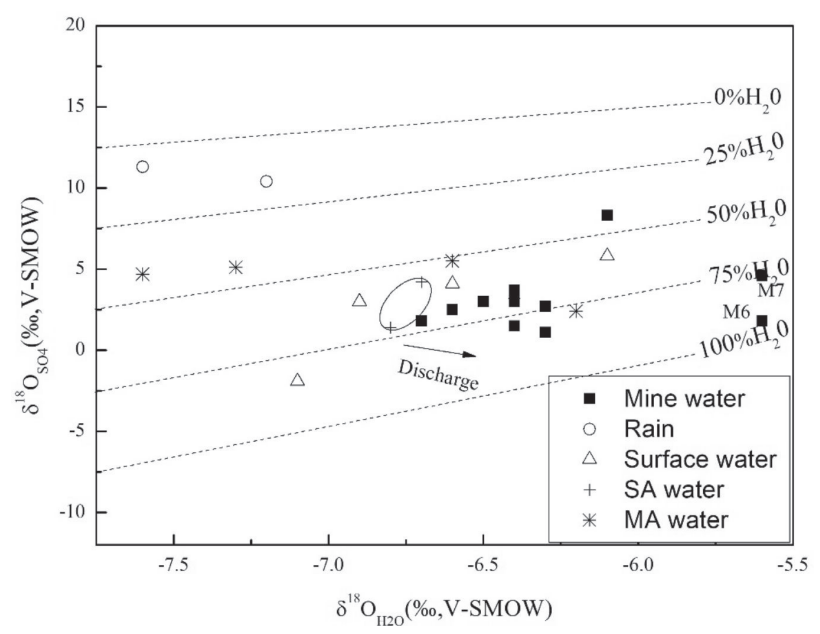

Fig. 11. Diagram comparing the $\delta^{18} \mathrm{O}$ composition of aqueous $\mathrm{SO}_{4}$ and coexisting water for samples collected in the study. 
the source of oxygen atoms in sulfate cations produced from the oxidation reaction between sulfide ore (brilliant and pyrite) and excess oxygen [44, 47]. As the sulfur element of the sulfite cations in the mine water comes from the sulfide oxidation process, the formation of high $\mathrm{Sb}$ water can be described as follows $[9,13]$ :

$$
\begin{gathered}
\mathrm{Sb}_{2} \mathrm{~S}_{3}+18 \mathrm{H}_{2} \mathrm{O}=2 \mathrm{SbO}_{3}^{-}+3 \mathrm{SO}_{4}^{2-}+26 \mathrm{e}^{-}+36 \mathrm{H}^{+} \\
\mathrm{Sb}_{2} \mathrm{~S}_{3}+3 \mathrm{H}_{2} \mathrm{O}+6 \mathrm{O}_{2}=2 \mathrm{Sb}_{2} \mathrm{O}_{3}+3 \mathrm{SO}_{4}^{2-}+6 \mathrm{H}^{+} \\
\mathrm{Sb}_{2} \mathrm{O}_{3}+3 \mathrm{H}_{2} \mathrm{O}=2 \mathrm{SbO}_{3}^{-}+4 \mathrm{e}^{-}+6 \mathrm{H}^{+} \\
\mathrm{SbO}_{3}^{-}+3 \mathrm{H}_{2} \mathrm{O}=\mathrm{Sb}(\mathrm{OH})_{6}^{-}
\end{gathered}
$$

In this process, oxygen atoms in $\mathrm{Sb}(\mathrm{OH})_{6}^{-}$are mainly derived from the oxygen gas. Oxidation of sulfide to sulfate, however, does not occur on the same timescale as the mobilization of antimony. Sulfate is possibly the final product of a sequence of slow reactions, in which algae and bacteria take the sulfur from its initial oxidation state -2 to $+6[13,29,48,49]$. Additionally, oxygen atoms in $\mathrm{SO}_{4}{ }^{2-}$ in $\mathrm{M} 6$ and $\mathrm{M} 7$ are mostly derived from water, which may also be due to the high waterflow rate in their sampling site.

\section{Formation Process of High Sb Mine Water}

Given the evidence presented above for the antinomy source of the mine water, the question is: how did this phenomenon occur?

It has been confirmed that the source of the antinomy of the mine water comes from the oxidation of $\mathrm{Sb}_{2} \mathrm{~S}_{3}$. The formation process of the high $\mathrm{Sb}$ mine water is described as follows. The MA water and the SA water generally have low $\mathrm{Sb}$ concentration $(<0.6 \mathrm{mg} / \mathrm{L})$ and the $\mathrm{Sb}$ element is mainly present in stibnite ore, which is a reducing environment. Once the ore body is exposed, the closed reducing environment immediately becomes an oxidizing environment. With the presence of an excess amount of oxygen gas, the sulfite in stibnite ore is oxidized to $\mathrm{S}^{4+}$ or $\mathrm{S}^{6+}$ (Equation (4)) and the $\mathrm{Sb}$ is oxidized to $\mathrm{SbO}_{3}^{-}$, a water-soluble anion (Equation (5)). This process also produces a large amount of $\mathrm{H}^{+}$as a by-product, which is rapidly neutralized by carbonate ores presented in the mine. Before the depletion of carbonate ores, the mine water will not become acidic, and the oxidation of stibnite will continue, resulting in high $\mathrm{Sb}$ mine water [49-51].

For safety reasons, the mining process requires continuous drainage, during which a large amount of drainage continuously flows into the groundwater funnel area or the lowest discharge area. Moreover, the accumulation of a large amount of mine water accelerates the formation of $\mathrm{Sb}(\mathrm{OH})_{6}^{-}$(Equations 4-6). Besides, when the mine water flows to the groundwater funnel area or the lowest discharge zone, part of the $\mathrm{Ca}^{2+}$ in the mine water is replaced by $\mathrm{Na}^{+}$and $\mathrm{K}^{+}$ in surrounding rock (silicified limestone) through ion-exchange interactions, resulting in a reduction of $\mathrm{Ca}^{2+}$ concentration and a rise of $\mathrm{Na}^{+}$and $\mathrm{K}^{+}$ concentrations. The high $\mathrm{Na}^{+}$and high $\mathrm{K}^{+}$water further contribute to the rise of the $\mathrm{Sb}$ content in the mine water. Thus, mine water with high $\mathrm{Sb}$, high sulfate salt, and high TDS is formed.

\section{Conclusions}

The mining process of the antimony deposit requires a large amount of drainage. As the amount of water inflow is greater than the amount of circulating water, the excess mine water must be discharged into the surrounding surface water bodies, resulting in $\mathrm{Sb}$ pollution. Recently, the surface water pollution from discharged mine water has received widespread attention. The sources and the formation processes of high $\mathrm{Sb}$ mine water are often neglected. In this study, the $\delta^{34} \mathrm{~S}\left(\mathrm{SO}_{4}\right)$ and $\delta^{18} \mathrm{O}\left(\mathrm{H}_{2} \mathrm{O}\right)$ data and the water-rock interactions are analyzed to reveal the $\mathrm{Sb}$ sources and geochemical behaviors of the mine drainage water in the largest $\mathrm{Sb}$ mine in China. The main conclusions obtained from this research are listed as follows:

1) The $\mathrm{Sb}$ concentrations in the mine water samples range from $1.19 \mathrm{mg} / \mathrm{L}$ to $12.10 \mathrm{mg} / \mathrm{L}$ with an average of $4.82 \mathrm{mg} / \mathrm{L}$, which is $238-2420$ times of China's national drinking water quality standards $(0.005 \mathrm{mg} / \mathrm{L})$ and 24.20 times the maximum acceptable $\mathrm{Sb}$ concentration of wastewater $(0.50 \mathrm{mg} / \mathrm{L})$, according to the local discharge regulations (Hunan Province, China). The chemical composition of the mine water is $\mathrm{Ca}-\mathrm{Na}-\mathrm{SO}_{4}$ type. The TDS value ranges from 855.00 to $2510.00 \mathrm{mg} / \mathrm{L}$, with an average of $1457.45 \mathrm{mg} / \mathrm{L}$, owning to the intensive mining activities.

2) The $\mathrm{Sb}$ contents in different water bodies vary a lot and have the following trend: mine water $>$ groundwater $>$ SA water $>$ MA water $>$ rain. Compared with other water bodies, the mine water has a higher amount of $\mathrm{Na}^{+}, \mathrm{TDS}$, and $\mathrm{SO}_{4}^{2-}$, indicating that the $\mathrm{Sb}$ element is more easily accumulated in the water bodies with high $\mathrm{Na}^{+}$, high TDS, and High $\mathrm{SO}_{4}{ }_{4}^{2-}$.

3) The $\delta^{18} \mathrm{O}\left(\mathrm{H}_{2} \mathrm{O}\right)$ and $\delta^{2} \mathrm{H}$ in the mine water samples are consistent with that of the SA water, indicating that the SA water is the main source of the mine water. Part of the MA water samples show a similar level of $\delta^{18} \mathrm{O}\left(\mathrm{H}_{2} \mathrm{O}\right)$ and $\delta^{2} \mathrm{H}$, suggesting that the MA aquifers are another water source of the mine water.

4) $\mathrm{The} \mathrm{Sb}$ in the mine water is mainly derived from the oxidation of stibnite. The surplus carbonate minerals accelerate the oxidation reaction of $\mathrm{Sb}_{2} \mathrm{~S}_{3}$, resulting in high $\mathrm{Sb}$ content mine water. Moreover, soluble oxygen in mine water promotes the formation of soluble $\mathrm{Sb}(\mathrm{OH})_{6}^{-}$. The high content of $\mathrm{Na}^{+}$and $\mathrm{K}^{+}$induced by the ion-exchange interaction also leads to the rise of $\mathrm{Sb}$ content in the mine water. 


\section{Acknowledgements}

The authors gratefully acknowledge the financial support provided by the Open Fund of State Key Laboratory of Groundwater Protection and Utilization by Coal Mining (No. SHJT-17-42.17), the Langfang Technology Research and Development Program (2018011064), the Fundamental Research Funds for the Central Universities of China (3142018009), and the Key Laboratory of Mine Geological Hazards Mechanism and Control Project (KF2017-13).

\section{Conflict of Interest}

The authors declare no conflict of interest.

\section{References}

1. HE M.C., WANG N.N., LONG X.J., ZHANG C.J.,MA C.L.,ZHONG Q.Y.,WANG A.H.,WANG Y., PERVAIZ A.,SHAN J.Antimony speciation in the environment: Recent advances in understanding the biogeochemical processes and ecological effects. J Environ Sci (China), 75, 14, 2019.

2. FU Z.Y., WU F.C., AMARASIRIWARDENA D., MO C.L., LIU B.J., ZHU J., DENG Q.J., LIAO H.Q. Antimony, arsenic and mercury in the aquatic environment and fish in a large antimony mining area in Hunan, China. Sci Total Environ, 408 (16), 3403, 2010.

3. WEN B., ZHOU J.W., ZHOU A.G.,XIE L.N. Sources, migration and transformation of antimony contamination in the water environment of Xikuangshan, China: Evidence from geochemical and stable isotope $(\mathrm{S}, \mathrm{Sr})$ signatures. Sci Total Environ, 569-570, 114, 2016.

4. WANG N.N., WANG A.H., KONG L.H., HE M.C. Calculation and application of Sb toxicity coefficient for potential ecological risk assessment. Sci Total Environ, 610-611, 167, 2018.

5. WANG N.N., WANG A.H., XIE J., HE M.C. Responses of soil fungal and archaeal communities to environmental factors in an ongoing antimony mine area. Sci Total Environ, 652, 1030, 2019.

6. HU X.Y., HE M.C., LI S.S., GUO X.J. The leaching characteristics and changes in the leached layer of antimony-bearing ores from China. Journal of Geochemical Exploration, 176, 76, 2017.

7. XU D.Y., GAO B., PENG W.Q., LI Y.Y. Geochemical and health risk assessments of antimony ( $\mathrm{Sb}$ ) in sediments of the Three Gorges Reservoir in China. Science of The Total Environment, 660, 1433, 2019.

8. WANG X.Q., HE M.C., XI J.H., LU X.F. Antimony distribution and mobility in rivers around the world's largest antimony mine of Xikuangshan, Hunan Province, China. Microchemical Journal, 97 (1), 4, 2011.

9. ZHU J. Environmental characteristics of water near the Xikuangshan antimony mine,Hunan Province. Acta Scientiae Circumstantiae, 29 (2), 655, 2009.

10. FILELLA M.B.N., CHEN J. Antimony in the environment a review focused on natural waters II. Relevant solution chemistry. Earth Science Reviews, 59, $265,2002$.
11. ZHU J., GUO J. Overview on Research on Environmentally Geochemical Characteristics of Antimony. Earth and Environment, 38 (1), 109, 2010.

12. HERATH I., VITHANAGE M., BUNDSCHUH J., Antimony as a global dilemma: Geochemistry, mobility, fate and transport. Environ Pollut, 223, 545, 2017.

13. ASHLEY P.M., CRAW D., GRAHAM B.P., CHAPPELL D.A. Environmental mobility of antimony around mesothermal stibnite deposits, New South Wales, Australia and southern New Zealand. Journal of Geochemical Exploration, 77 (1), 1, 2003.

14. BOTTRELL S., TELLAM J., BARTLETT R., HUGHES A. Isotopic composition of sulfate as a tracer of natural and anthropogenic influences on groundwater geochemistry in an urban sandstone aquifer, Birmingham, UK. Applied Geochemistry, 23 (8), 2382, 2008.

15. NARIYAN E., WOLKERSDORFER C., SILLANPAA M. Sulfate removal from acid mine water from the deepest active European mine by precipitation and various electrocoagulation configurations. J Environ Manage, 227, $162,2018$.

16. SAMBORSKA K., HALAS S. ${ }^{34} \mathrm{~S}$ and ${ }^{18} \mathrm{O}$ in dissolved sulfate as tracers of hydrogeochemical evolution of the Triassic carbonate aquifer exposed to intense groundwater exploitation (Olkusz-Zawiercie region, southern Poland). Applied Geochemistry, 25 (9), 1397, 2010.

17. TEMOVSKI M., FUTO I., TURI M., PALCSU L. Sulfur and oxygen isotopes in the gypsum deposits of the Provalata sulfuric acid cave (Macedonia). Geomorphology, 315, 80, 2018.

18. ZHOU J.W., ZHANG Q.X., KANG F.X., ZHANG Y.P., YUAN L., WEI D., LIN S.H. Using multi-isotopes $\left({ }^{34} \mathrm{~S}\right.$, $\left.{ }^{18} \mathrm{O},{ }^{2} \mathrm{H}\right)$ to track local contamination of the groundwater from Hongshan-Zhaili abandoned coal mine, Zibo city, Shandong province. International Biodeterioration \& Biodegradation, 128, 48, 2018.

19. GAMMONS C.H., BROWN A., POULSON S.R., HENDERSON T.H. Using stable isotopes (S, O) of sulfate to track local contamination of the Madison karst aquifer, Montana, from abandoned coal mine drainage. Applied Geochemistry, 31, 228, 2013.

20. LI Q.G., JU Y.W., LU W.Q., WANG G.C., NEUPANE B., SUN Y. Water-rock interaction and methanogenesis in formation water in the southeast Huaibei coalfield, China. Marine and Petroleum Geology, 77, 435, 2016.

21. REDWAN M., ABDEL MONEIM A.A., AMRA M.A. Effect of water-rock interaction processes on the hydrogeochemistry of groundwater west of Sohag area, Egypt. Arabian Journal of Geosciences, 9 (2), 2016.

22. SALCEDO SANCHEZ E.R., GARRIDO HOYOS S.E., VICENTA ESTELLER M., MORALES M.M., ASTUDILLO A.O.Hydrogeochemistry and water-rock interactions in the urban area of Puebla Valley aquifer (Mexico). Journal of Geochemical Exploration, 181, 219, 2017.

23. TALAVERA MENDOZA O., RUIZ J., DIAZ VILLASENOR E., RAMIREZ GUZMAN A., CORTES A.,SALGADO SOUTO S.A., DOTOR ALMAZAN A., RIVERA BUSTOS R. Water-rock-tailings interactions and sources of sulfur and metals in the subtropical mining region of Taxco, Guerrero (southern Mexico): A multi-isotopic approach. Applied Geochemistry, 66, 73, 2016.

24. ZHOU J.W., NYIRENDA M.T., XIE L.N., ZHOU B.L., ZHU Y., LIU H.L. Mine waste acidic potential and distribution of antimony and arsenic in waters of the 
Xikuangshan mine, China. Applied Geochemistry, 77, 52, 2017.

25. FU Z.Y., WU F.C., MO C.L., DENG Q.J., MENG W., GIESY J.P. Comparison of arsenic and antimony biogeochemical behavior in water, soil and tailings from Xikuangshan, China. Sci Total Environ, 539, 97, 2016.

26. WEN B., ZHOU A.G., ZHOU J.W., LIU C.F., HUANG Y.L., LI L.G. Coupled $\mathrm{S}$ and $\mathrm{Sr}$ isotope evidences for elevated arsenic concentrations in groundwater from the world's largest antimony mine, Central China. Journal of Hydrology, 557, 211, 2018.

27. GUO X.J., WU Z.J., HE M.C., MENG X.G., JIN X., QIU N., ZHANG J. Antimony smelting process generating solid wastes and dust: characterization and leaching behaviors. J Environ Sci (China), 26 (7), 1549, 2014.

28. PIPER M. Graphic procedure in the geochemical interpretation of water-analyses. Hydrology, 914, 1944.

29. BIVER M., SHOTYK W. Stibnite $\left(\mathrm{Sb}_{2} \mathrm{~S}_{3}\right)$ oxidative dissolution kinetics from $\mathrm{pH} 1$ to 11 . Geochimica et Cosmochimica Acta, 79, 127, 2012.

30. TAHERI M., MAHMUDY GHARAIE M.H., MEHRZAD J., AFSHARI R., DATTA S.Hydrogeochemical and isotopic evaluation of arsenic contaminated waters in an argillic alteration zone. Journal of Geochemical Exploration, 175, 1, 2017.

31. GAMMONS C.H., POULSON S.R., PELLICORI D.A., REED P.J., ROESLER A.J., PETRESCU E.M. The hydrogen and oxygen isotopic composition of precipitation, evaporated mine water, and river water in Montana, USA. Journal of Hydrology, 328 (1-2), 319, 2006.

32. CRAIG H. Isotopic Variations in Meteoric Waters. SCIENCE, 133, 1702, 1961.

33. WU H., ZHANG X., SUN G. Variations of stable Isotope Characteristics of Atmospheric Precipitation from Changsha, Hunan. Resources and Environment in the Yangtaze Basin, 21 (5), 540, 2012.

34. HUANG Y., ZHANG X., TANG F. Variations of Precipitation Stable Isotope and Vapor Origins Revealed by Deuterium Excess in Changsha. JOURNAL OF NATURAL RESOURCE, 28 (11), 1945, 2013.

35. HAO C.M., HUANG Y., MA D.J. Isotope Drift Characteristics in Ordovician Limestone Karst Water Caused by Coal Mining in Northern China. Mine Water and the Environment, 2019.

36. KIM D.M., YUN S.T., YOON S.M., MAYER B. Signature of oxygen and sulfur isotopes of sulfate in ground and surface water reflecting enhanced sulfide oxidation in mine areas. Applied Geochemistry, 100, 143, 2019.

37. YANG S. On Inquiry about the Genesis of Human Stibnite ore and the direction of the Search. Hunan Geology, 5 (4), $12,1986$.
38. TAO Y., GAO Z., JIN J. The Origin of Ore Forming Fluid of Xikuangshan Type Antimony Deposits in Central Hunan Province. Geology Geochemistry, 29 (1), 14, 2001.

39. LIU J., CAI W., CAO Y. Hydrochemical Characteristics of Gronudwater and the origin in Alluvial-proluvial Fan of Qinhe River. Environmental Science, 39 (12), 5428, 2018.

40. JALALI M. Major ion chemistry of groundwaters in the Bahar area, Hamadan, western Iran. Environmental Geology, 47 (6), 763, 2005.

41. KIM K.J., RAJMOHAN N., KIM H.J., HWANG G.S., CHO M.J. Assessment of groundwater chemistry in a coastal region (Kunsan, Korea) having complex contaminant sources: a stoichiometric approach. Environmental Geology, 46 (6-7), 7634, 2004.

42. GUO H., WANG Y. Geochemical characteristics of shallow groundwater in Datong basin, northwestern China. Journal of Geochemical Exploration, 87 (3), 109, 2005.

43. KAUR L., RISHI M.S., SHARMA S., SHARMA B., LATA R., SINGH G. Hydrogeochemical characterization of groundwater in alluvial plains of river Yamuna in northern India: An insight of controlling processes. Journal of King Saud University - Science, 2019.

44. SUN J., KOBAYASHI T., STROSNIDER W.H.J., WU P. Stable sulfur and oxygen isotopes as geochemical tracers of sulfate in karst waters. Journal of Hydrology, 551, 245, 2017.

45. TAYLOR B.E., WHEELER M.C. Sulfur- and OxygenIsotope Geochemistry of Acid Mine Drainage in the Western United States, 550, 481, 1993.

46. SUN J., TANG C.Y., WU P., STROSNIDER WH.J., HAN Z.W. Hydrogeochemical characteristics of streams with and without acid mine drainage impacts: A paired catchment study in karst geology, SW China. Journal of Hydrology, 504, 115, 2013.

47. SEAL S., KUIRY S.C., HEINMEN B. Effect of glycine and hydrogen peroxide on chemical-mechanical planarization of copper. Thin Solid Films, 423, 243, 2003.

48. LI S.X., ZHENG F.Y., HONG H.S. Photo-oxidation of $\mathrm{Sb}$ (III)in the seawater by marine phytoplankton-transition metals-light system. Chemosphere, 65 (8), 1432, 2006.

49. WANG X.Q., HE M.C., LIN C.Y., GAO Y.X., ZHENG L. Antimony(III) oxidation and antimony(V) adsorption reactions on synthetic manganite. Geochemistry, 72, 41, 2012.

50. GUO X., WU Z., HE M. Removal of antimony(V) and antimony(III) from drinking water by coagulationflocculation-sedimentation (CFS). Water Res, 43 (17), 4327, 2009.

51. XI J., HE M., LIN C. Adsorption of antimony(III) and antimony $(\mathrm{V})$ on bentonite: Kinetics, thermodynamics and anion competition. Microchemical Journal, 97 (1), 85, 2011. 